\title{
Brachial Plexus
}

National Cancer Institute

\section{Source}

National Cancer Institute. Brachial Plexus. NCI Thesaurus. Code C12682.

A nerve network originating from $\mathrm{C} 5$ to $\mathrm{T} 1$ that supplies cutaneous and muscular innervation to the arm and hand. 